\title{
The Impact of Legal Land Acquisition for Public Interest
}

\author{
${ }^{1}$ Isye Melo* \\ Law Studies Program \\ Faculty of Social Sciences, \\ Universitas Negeri Manado \\ Manado, Indonesia \\ isyemelo@unima.ac.id
}

\author{
Feibe Engeline Pijoh \\ Law Studies Program \\ Faculty of Social Sciences, \\ Universitas Negeri Manado \\ Manado, Indonesia \\ feibepijoh@gmail.com
}

\begin{abstract}
This research focusing on how is the legal arrangements for implementing land acquisition for the public interest and what is the impact legal of land acquisition for the public interest to land rights holders? This study aimed to find out and describe the legal arrangements for implementing land acquisition for the public interest and to analyze the impact for land rights holders from the implementation of land acquisition for the public interest. The specific target to be achieved in this research is to improve government policies related to the interests of land rights holders. The method used in this research is the normative legal research method, which is one of the commonly known studies in the field of legal science to study its positive legal substance textually (not limited to norms, but also principles, even values contained). This research begins with an inventory of various legal materials for further analysis and the results of this analysis become a strategy to create better policies.
\end{abstract}

Keywords: legal land acquisition, land, public interest

\section{INTRODUCTION}

The land is a very important asset and the basic capital of development. There are almost no development activities (in the sectoral field) that do not require land utility. Development activities conducted in all areas of life, especially for the public interest, always need land as a container for the construction to be placed. Recently, the development continues to increase and without stopping, but the supply of land is increasingly difficult and limited. These circumstances can "create conflict due to public interests and individuals or groups collide each other". Such conditions require wise and fair regulatory efforts to avoid conflicts that occur in society. The government as the policymaker has made efforts by issuing regulations on land acquisition for development in the public interest. It aims to "avoid conflicts that occurred". However, the implementation often encountered obstacles that lead to a deadlock causing the development process is hampered.

The issue of land acquisition and revocation of rights always involves two things that should be placed in a balanced manner, namely the "government interest" and "the community interest". The two parties involved, namely the "Ruler" and "the People" should pay attention to each other and comply with the prevailing regulations.
If this is not heeded, problems will arise as we often read in various mass media publications, where the authorities with their "compulsion" conducting actions are deemed contrary to human rights and so on, meanwhile the people want it or not, they need to do anything as their believed, which are the rights that they defend.

The governments' assessment is conducted differently. "All regulations relating to the matter have been deemed, although there are still many implementing officials who do not understand correctly or have different interpretations of the provisions governing the matter." However, it is also not impossible the provision is felt to be quite restrictive to them for it is difficult to take the best "policy" in the matter. However, for the people, the treatment imposed on their land will only be considered as detrimental or not. It is clear they have internal measurements related to various interests and regarding the "value" of the land, for the values that factual and some are ideals. As an issue in land acquisition cannot possibly revolve around fact value, and they are still required to "sacrifice" or make sacrifices in the form of being willing to reduce their demand from the existing value.

"The government implemented the exemption mostly used for the construction of government projects or public facilities, such as government offices, roads, ports, airports, etc. The dispute pattern ranges; between the people and the government, between the people and the private sector (supported by the government) regarding the amount of compensation between the people and the plantation and forestry parties regarding cultivated land between the people themselves regarding matters of ownership, cultivation, inheritance, leasing. That the dispute was partly due to manipulation by officials or the land acquisition committee and the small compensation for the land taken. "

"In general, people do not understand the legal provisions regarding land acquisition, for they are confused by the government's policy to take their land improperly. Ignorance or anything they can do concerning what they want to do. The problem cannot be judged whether the act violates the law or not. This situation is un identify to the person who needs the land, 
but for various reasons to carry out the project that has been planned, the acquisition is still conducted with compensation." It is difficult for those who need land to determine to whom the compensation is given. Therefore, there are many compensation payments made to people who are not entitled to cause disputes. "The juridical provisions governing the existence of land are contained in Law No. 5/1960 concerning Basic Agrarian Regulations (hereinafter referred to as UUPA), which is an implementation of the provisions of Article 33 paragraph (3) of the 1945 Constitution which states the land and water and natural resources contained are controlled by the State and used for the greatest welfare of the people.

For further manifestations of land are widely spread in various other laws and regulations such as Government Regulation Number 40 of 1996 concerning Business Use Rights, Building Use Rights, and Land Use Rights; Regulation of the Minister of Agrarian Affairs / Head of the National Land Agency Number 3 of 1999 concerning Delegation of Authority to Grant and Cancellation of Decisions on Granting Land Rights; and others."

The legal policy regarding "restrictions on ownership of land rights applied in the articles of the LoGA an idealistic theoretical setting seems to reflect the ideals of the formation of the UUPA itself which primarily aimed as follows"[1]:

1. "Laying the foundations for the formulation of a national agrarian law which will be a tool to bring prosperity, happiness, and justice to the State and the people, especially the peasants, in the framework of a just and prosperous society".

2. "Laying the foundations for unity, and simplicity in the law of the land.

3. "Laying the groundwork to provide legal certainty regarding land rights for the entire people."

From the background description above, the problems in this study are:

1. How is the legal arrangement for land acquisition for the public interest?

2. What is the impact of legal land acquisition in the public interest for land rights holders?

\section{RESEARCH METHODS}

This is using the normative legal research method, which is "as one of the commonly known studies in the field of law science to examine the positive legal substance textually (not limited to the norms, but also principles, even the values contained) [2]. In this study, the approaches used are the statute approach, the case approach, and the conceptual approach.

The technique of collecting legal materials used in this research is through library research, namely collecting, studying, and examining legal materials that have relevance to the issues formulated, both for primary legal materials, secondary legal materials, and tertiary legal materials.

In this study, the legal materials obtained are presented, categorized, and arranged systematically for later analysis by abstracting the existing laws and regulations to answer questions or to solve problems. The analysis of legal materials is descriptive. In the qualitative juridical analysis method, the legal materials or research objects used are not only to describe, but legal arguments will also be provided.

\section{RESULT AND DISCUSSION}

\section{Regulation of Land Acquisition for Public Interest}

The rapid development in various sectors exist today demands regional expansion in various places and regions for the realization of equitable development. However, it is realized often creates conflicts in the community. Problems related to the acquisition of land for a public interest, from time to time, always create polemics that difficult to resolve due to collisions with various interests. Besides, the state guarantees individual legal ownership of land, meanwhile, the executor of state power, namely the government is obliged to conduct the agenda of physical infrastructure development which often has sacrifice the value of individual interests. The public interest which is defined from the social function of the land is no less important than the interest of the individual owner which is translated from the economic function of the land.

Numbers of regulations were issued by the Government to regulate national land policy, the essence of which is to administer land use to create order and guarantee legal certainty for everyone who has a legal relationship to the land. These regulations include:

1. "Law Number 2 of 2012 concerning Land for Development for Public Interest (State Gazette of the Republic of Indonesia of 2012 Number 22, Supplement to the State Gazette of the Republic of Indonesia Number 5280)".

2. "Government Regulation Number 27 of 2014 concerning Management of State / Regional Property (State Gazette of the Republic of Indonesia of 2014 Number 92, Supplement to the State Gazette of the Republic of Indonesia Number 5533).

3. "Presidential Regulation Number 71 of 2012 concerning Implementation of Land acquisition for Development for Public Interest (State Gazette of the Republic of Indonesia of 2012 Number 156) as amended several times, most recently by Presidential Regulation Number 148 of 2015 concerning the Fourth Amendment of Presidential Regulation Number 71 of 2012 concerning Implementation of Land acquisition for Development for Public Interest (State Gazette of the Republic of Indonesia of 2015 Number 366) ";

4. "Presidential Regulation Number 3 of 2016 concerning Acceleration of Implementation of 
National Strategic Projects (State Gazette of the Republic of Indonesia of 2016 Number 4) as amended several times, most recently by Presidential Regulation Number 56 of 2018 concerning Second Amendment to Presidential Regulation Number 3 of 2016 concerning Acceleration Implementation of National Strategic Projects (State Gazette of the Republic of Indonesia of 2018 Number 107)";

5. "Presidential Decree 66/2020 concerning Funding for Land acquisition for Development in the Public Interest in the Implementation of National Strategic Projects".

"In-Law Number 2 of 2012 concerning Land acquisition for Public Interest Development, it describes public interests are classified into three types, namely the interests of the nation, state, and society. More clearly, regulating land for the public interest is regulated in Article 10 of Law Number 2 of 2012 which states land is used for development" [3]:

a. "National defense and security.

b. "Public roads, toll roads, tunnels, railways, train stations, and railway operating facilities.

c. Reservoirs, dams, weirs, irrigation, drinking water channels, sewerage and sanitation, and other irrigation structures.

d. "Ports, airports, and terminals.

e. "Oil, gas, and geothermal infrastructure.

f. "Electricity generation, transmission, substation, network and distribution"

g. "Government telecommunications and informatics networks.

h. "Waste disposal and processing sites.

i. "Government / Local Government hospitals.

j. "Public safety facilities.

k. "Government / Local Government public burial places.

1. "Social facilities, public facilities, and public green open spaces.

m. "Nature reserves and cultural heritage.

n. "Government / Local Government/village offices.

o. "Arrangement of urban slum settlements and/or land consolidation, as well as housing for low-income communities with rental status.

p. "Educational infrastructure or government / regional government schools.

q. "Government / Regional Government sports infrastructure; and

r. "Public markets and public parking lots".

Furthermore, " Presidential Regulation 66/2020 concerning Funding for Land acquisition for Development in the Public Interest, is a regulation which includes the Implementation of National Strategic Projects which aim to accelerate land acquisition funding for development in the public interest in the context of implementing National Strategic Projects which have been stipulated by the Regulation. President Number 102 of 2016 concerning Funding of Land acquisition for Development of Public Interest in Implementing National Strategic Projects.

\section{The Impact of Land Acquisition for Public Interest of Land Rights holders}

The 1945 Constitution in Article 33 paragraph (3) has provided the basis of the land and water as well as the natural resources contained are controlled by the state and used as much as possible for the welfare of the people. From these basic provisions, it can be stated the prosperity of a society is the main objective in the utilization of the functions of the earth, water, and space as well as the natural resources contained. Thus, the authority granted by the 1945 Constitution, is not as an own authority but the State is given the authority to regulate and determine the designation, use, and maintenance of the earth, water, and natural resources contained, including regulating legal relations. People and legal actions as well as rights that can be controlled relating to the earth, water, and natural resources contained.

"The right to control from this country also contains Article 2 of the UUPA as follows" [1]:

1) "On the provisions in Article 33 paragraph (3) of the Basic Law and matters referred in Article 1, the earth, water and space, including the natural resources contained, at the highest level controlled by the State as an organization for all people. "

2) (2) "The right to control of the State referred to in paragraph (1) of this article authorizes:

a. Regulate and administer the allotment, use, supply, and maintenance of the earth, water, and space,

b. Determine and regulate the legal relationship between people and earth, water, and space,

c. Determine and regulate legal relationships between people and legal actions concerning the earth, water, and space.

3) The authority deriving from the right to control of the State as meant in paragraph (2) of this article is used to achieve the greatest possible prosperity of the people, in the sense of happiness, welfare and independence in society and the Indonesian constitutional state which is independent, sovereign, justice and prosperous.

4) The exercise of the right to control of the State can be delegated to the Swatantra areas and customary law communities, just as necessary and accordance with the national interest, according to the provisions of the Government Regulation. "

Land acquisition activities should be based on the principle of respect for land rights to achieve a balance between public interests and individual interests. This principle is then further elaborated into the principle of agreement in the provisions of Article 2 letter f of Law 
Number 2 of 2012 as follows: agreement means "principle of agreement" is the land acquisition conducted by deliberation of the parties without coercion to obtain a mutual agreement.

"The deliberation process is the same as the negotiation process in an agreement where the parties try to reconcile their respective desires to achieve a win-win solution. The arrangement for deliberation was first regulated in Minister of Home Affairs Number 15 of 1975 concerning Provisions regarding Procedures for Land Acquisition in the provisions of Article 1 paragraph (3) which stipulates: to conduct its duties, the land acquisition committee shall be guided by the applicable regulations based on the principle of deliberation and local general prices. The implementation of this deliberation is not regulated in detail. The provisions of Article 6 paragraph (1) only stipulate: In conducting an assessment/determination of the amount of compensation, of the Land Acquisition Committee should do deliberations to the owners/holders of land rights and/or objects/plants on it based on local general prices. "

During its development, the land problem is increasingly complex. In terms of compensation and resettlement, it should be followed by activities to restore the socio-economic life of the community by taking into account the losses suffered by residents who felt the impact of land acquisition. For residents of the community, whose land was previously a valuable asset, as a place of business, farming, gardening and so on, are forced to lose this asset due to their land must be freed for their ownership rights related to land acquisition for public purposes, so they must be moved to a new settlement.

Land acquisition for development is the most complicated if an agreement is not reached between the land's owner and the construction party, while the construction should be conducted. One solution that can be chosen by the Government is to complete development in a way that is acceptable to society. The law should guarantee the availability of land parcels for various purposes related to state administration, but the law should also pay attention to the rights of the people, its certainty should be guaranteed not to become victims of arbitrary development.

Jeremy Bentham in Satjipto Rahardjo in his view on the usefulness of law, states the enactment of a legal provision should consider the positive impact. Bentham as a figure from Utilitarianism emphasizes a necessity in a legal system, that the formation of law should form a just law for all citizens of society individually [4]. This includes justice for holders of land rights who have experienced land acquisition for public purposes. Where there is a guarantee after the land acquisition is agreed upon, there will be a life that economically better than before, due rights have been released economically cannot be valued in money [5].
"Law No.2 of 2012 in Article 1 point 10 has formulated that compensation is a reasonable and fair compensation to entitled parties in the land acquisition process. Compensation as an effort to realize respect for the rights and interests of individuals who have been sacrificed for the public interest, can be called fair, if it does not make someone richer, or otherwise poorer than the original situation [6]. To be fair to rights holders, certain criteria should be applied objectively, with predetermined standards. Besides, the final determination of the amount of compensation should be reached by deliberation between the right holder and the agency requiring the land. For buildings, the estimated compensation takes into account the costs incurred for necessary repairs, after the announcement of the land acquisition. "

"The policy regarding the provision of compensation is not limited to the replacement of the value of land, buildings, and plants, but should also include an assessment of immaterial losses and arise, such as business activities, due to moving to other places, the number of customers and reduced profits".

Compensation can be given in the form of [3]: a. money; b. replacement land; resettlement; $d$. shareholding; or e. other forms agreed by both parties. For the right to build on land does not belong to him, Compensation is given to the holder of the right to build or use the right to build a plant or other object related to the land he owns, while Compensation for the land is given to the owner of the property or management right.

In determining compensation, the Land Agency shall conduct deliberations with the entitled parties within 30 (thirty) working days from the time the appraiser's assessment results are submitted to the Land Agency to determine the form and/or amount of compensation based on the results of the Compensation assessment. The result of the agreement in the deliberation becomes the basis for the provision of Compensation to the Eligible Party which is included in the minutes of the agreement.

If there is a refusal from the entitled party regarding the form and/or amount of Compensation but does not file an objection within 14 (fourteen) times after the deliberation to determine Compensation, then due to the law the Entitled Party is deemed to have accepted the form and amount of compensation.

When the implementation of compensation and relinquishment of rights has been conducted or the provision of compensation has been deposited in the district court, the ownership of land rights of the entitled party is canceled and the evidence of their rights is declared invalid and the land becomes land directly controlled by the state.

\section{CONCLUSION}

In its development, there are several regulations relating to land acquisition for the public interest. A 
number of these regulations were issued by the Government to administer land use to create order and ensure legal certainty for everyone who has a legal relationship with the land. Law Number 2 of 2012 specifically regulates land acquisition for the development of public interests.

The legal consequences of land acquisition for the public interest for land rights holders include the fact that the land acquisition process is conducted by deliberation of the parties without coercion to obtain a collective agreement. The arrangement for deliberation was first regulated in Regulation of the Minister of Home Affairs Number 15 of 1975 concerning Provisions regarding Procedures for Land Acquisition. Then there is legal certainty in terms of compensation and resettlement which should be followed by activities to restore the socio-economic life of the community by taking an account of the losses suffered by residents affected by the impact of land acquisition. For community members, whose land was previously a valuable asset, as a place of business, farming, gardening and so on, are forced to lose these assets because their land ownership rights should be released about land acquisition for public purposes, they should be moved to a residential new area.

\section{ACKNOWLEDGMENT}

All Glory is only for God who bestows reason and knowledge on mankind, for the knowledge and wisdom from God, the author able to complete this research article. The authors acknowledge those who have helped and have provided input and corrections to make this paper perfect. In particular, the authors would like to thank Prof. Dr. Julyeta P.A. Runtuwene, MS as the Rector of Manado State University, Dr. Apeles Lexi Lonto, M.Si as Dean of the Faculty of Social Science, and all the IJCST Review Team. It is realized this research still needs to be improved, therefore we ask for criticism and suggestions for the perfection of this paper. Hopefully, this article will useful.

\section{REFERENCES}

[1] Pemrintah Indonesia, 'Undang-undang Nomor 5 Tahun 1960 tentang Peraturan Dasar PokokPokok Agraria'. Pemerintah Indonessia, Jakarta, 1960.

[2] A. Muhammad, Hukum dan Penelitian Hukum. Bandung: Citra Aditya Bakti, 2004.

[3] Pemerintah Indonesia, 'Undang-undang No. 2 Tahun 2012 tentang Pengadaan Tanah Bagi Pembangunan Untuk Kepentingan Umum'. Pemerintah Indonessia, Jakarta, 2012.

[4] J. Bentham, 'Introduction to the Principles of Morals and Legislation, 1948 edition'. New York: Hafner Publishing Company, 1789.

[5] S. Rahardjo, 'Ilmu Hukum, Bandung: Citra Aditya Bakti, 1996. Rawls, John., A Theory of Justice'. London: Oxford University press, yang sudah diterjemahkan dalam bahasa ..., 2006.

[6] M. S. Sumardjono, Kebijakan pertanahan: antara regulasi dan implementasi. Jakarta: Kompas, 2006. 